\title{
A HIV/AIDS és a jog Magyarországon
}

\author{
Julesz Máté dr.
}

Szegedi Tudományegyetem, Igazságügyi Orvostani Intézet, Szeged

\begin{abstract}
Bevezetés: A HIV/AIDS jogi vonatkozásai legtisztábban a statisztikai számadatokból tűnnek ki. Célkitüzés: Kifejezni a HIV/AIDS hatását a mai magyar társadalomra. Módszer: Az Országos Epidemiológiai Központ és a szakirodalom adatainak elemzése, valamint a magyar joggyakorlat vizsgálata. Eredmények: A magyar bíróságok enyhítő körülményként értékelik a büntetéskiszabáskor, ha az elkövető AIDS-ben szenved. Az Országos Epidemiológiai Központ adatai szerint 1985-ben 16 regisztrált HIV-fertőzött volt Magyarországon. 1995-ben már 81-en, 2005-ben 107-en, míg 2015-ben 201-en voltak. 2005-ben a regisztrált 107 HIV-fertőzöttből 10-en voltak névtelenek, míg 2015-ben 201ből 37-en ôrizték meg anonimitásukat. A nem anonim HIV-fertőzöttek ismert adatai szerint a HIV-fertőzött férfiak száma többszöröse a HIV-fertőzött nőkének, és ez az évek folyamán végig így alakul. A HIV-vel összefüggő halálozások száma elenyészően alacsony Magyarországon, de körükben is nagyobb a férfiak aránya, mint a nőké. Következtetések: A HIV/AIDS terén a latencia gondot okoz az egészségügyi és a jogi prevenció alkalmazásakor. Fontos, hogy az egészségügyi adatok védelme megmaradjon, de ez ne korlátozza a HIV/AIDS prevencióját. Orv. Hetil., 2016, 157(47), 1884-1890.
\end{abstract}

Kulcsszavak: HIV, AIDS, egészségügyi prevenció, jogi prevenció, büntetéskiszabás gyakorlata, orvosi jog

\section{HIV/AIDS and law in Hungary}

\begin{abstract}
Introduction: The legal aspects of HIV/AIDS are mirrored by the statistical data. Aim: The aim of the author is to show the effect of HIV/AIDS on today's Hungarian society. Method: Analysis of data issued by the National Center for Epidemiology in Hungary and those to be found in the professional literature, as well as analysis of the Hungarian legal practice. Results: Hungarian courts tend to impose a lighter punishment on a perpetrator diagnosed with AIDS than on a healthy perpetrator. According to the data issued by the Hungarian Epidemiological Center, in 1985, 16 HIV-contaminated persons were registered in Hungary; in 1995, 81, in 2005, 107, whilst in 2015, 201 HIV-contaminated persons were registered in Hungary. In 2005, 10 of the $107 \mathrm{HIV}$-contaminated persons were anonymous, whilst, in 2015,37 of the 201 HIV-contaminated persons were anonymous. According to the known data of not anonymous HIV-contaminated persons, the number of males predominates largely over the number of females and this has been the case during the past decades. In Hungary, only a small proportion of the HIV-contaminated persons have died: the number of males predominates over the number of females. Conclusions: As to HIV/ AIDS, latency poses problems in the field of healthcare prevention and legal prevention. It seems to be important to protect data relating to healthcare, though the data protection should not impede the prevention of HIV/AIDS.
\end{abstract}

Keywords: HIV, AIDS, healthcare prevention, legal prevention, practice of criminal punishment, medical law

Julesz, M. [HIV/AIDS and law in Hungary]. Orv. Hetil., 2016, 157(47), 1884-1890.

(Beérkezett: 2016. szeptember 28.; elfogadva: 2016. október 15.)

\section{HIV/AIDS és egyenlő bánásmód Magyarországon}

Az AIDS szerzett immunhiányos tünetegyüttest jelent, amelyet a HIV, tehát az emberi immunhiány vírusa idéz elő. 1981. december 1. óta jegyzett betegség, de már a XX. század első felében kezdett elterjedni. Kétségtelen, hogy a fertőzöttek nagy száma Afrikából kerül ki. Ez azonban nem jelenti azt, hogy a fejlett világ országai ne lennének fertőzöttek. Magyarországon viszonylag alacsony - néhány ezres - lélekszámra becsülik a HIV-fertőzötteket, de általánosan kötelező szűrés hiányában ez az adat pontatlan. A HIV-szürés a polgári jogi személyiségvédelem és a közigazgatási járványügy küzdelmének színterévé vált. Járványügyi szempontból indokolt volna az AIDS-betegségben szenvedőknek, illetve a HIV-fer- 
tőzötteknek a jelenleginél szélesebb körű detektálása, de fejlett személyiségvédelmi jogunk és az egészségügyi önrendelkezés joga - nem éppen alaptalanul - visszafogja a járványügyi közjogi szempontok érvényesülését. A közérdek felülírja a magánérdeket, de a betegek individuális érdekei (például családalapítás, munkavállalás stb.) megkívánják, hogy a jogalkotó csak konkrétan meghatározott, pontosan körülírt jogállami célból tegye kötelezővé a HIV-tesztet. A polgári jogból ismert személyiségvédelem a munkajogban is érvényesül. A munka törvénykönyvének 9 . $\$(2)$ bekezdése értelmében a munkavállaló személyiségi joga akkor korlátozható, ha a korlátozás a munkaviszony rendeltetésével közvetlenül összefüggó okból feltétlenül szükséges és a cél elérésével arányos. További fontos szabály, hogy például a munkavállaló személyiségi jogának az AIDS-betegségére, illetve HIV-fertőzöttségére tekintettel alkalmazott korlátozásáról, annak módjáról, feltételeiről és várható tartamáról a munkavállalót előzetesen tájékoztatni kell. Egészségügyi törvényünk 59 . $\$$ (4) bekezdése értelmében az egészségügyi államigazgatási szerv külön rendelkezése nélkül is, járványügyi érdekből HIV-ellenanyagvizsgálatnak köteles alávetni magát:

- aki foglalkozása vagy önkéntes munkavégzése keretében, vagy jövedelemszerző tevékenysége során saját vére vagy váladéka útján a vírust más személynek továbbadhatja, illetve más személyek vérével és váladékával fertőződhet (például orvosok vagy egészségügyi szakdolgozók);

- a véradásra donorként jelentkező és a véradásban való részvételre alkalmas személy;

- saját anyatejet más számára adományozó nő;

- a szerv- vagy szövetátültetés céljából - élő személyből vagy halottból - eltávolított szervet, szövetet adományozó vagy a kivétel ellen életében tiltakozó nyilatkozatot nem tett személy;

- a Btk. szerint a nemi élet szabadsága és a nemi erkölcs elleni bűncselekménnyel, a kábítószer-kereskedelemmel, a kábítószer birtoklásával, a kóros szenvedélykeltéssel, a kábítószer készítésének elősegítésével, az új pszichoaktív anyaggal való visszaéléssel, valamint a személy elleni erőszakkal vagy személyi sérülés okozásával elkövetett búncselekménnyel gyanúsított, illetve vádolt olyan személy, aki az elkövetés során a fertőződést átadhatta vagy fertőződhetett, valamint az ilyen büncselekmény sértettje, ha a fertőződés kockázata fennáll;

- továbbá az a személy, akinek vizsgálatát a bíróság a fertőzés lehetőségének tisztázása céljából elrendelte.

A felsorolt eseteken túl is adódhatnak olyan helyzetek, amelyekben a HIV-tesztnek kénytelen magát alávetni például az életbiztosítási szerződést kötő személy. Ha nem teszi meg, akkor a biztosítót nem lehet szerződéskötésre kötelezni.

A 18/2002. (XII. 28.) ESzCsM rendelet 7. $\$$-a értelmében az egészségügyi szolgáltatások nyújtása során a betegellátással összefüggő tevékenységet úgy kell meg- szervezni, hogy a HIV-vel történő fertőződés lehetőségét a munkavédelmi és a kórházhigiénés szabályok betartásával a lehető legkisebb mértéküre csökkentsék. Ha az egészségügyi dolgozót tevékenysége közben HIV-fertőzött vérrel tû- vagy éleseszköz-sérülés, vagy tartós nyálkahártya-, illetve bőrexpozíció ért, a közvetlen ellátása után a munkáltató felméri, hogy kialakulhat-e fertőződés, és, ha igen, akkor fel kell ajánlani a megelőző kezelést. A 18/1998. (VI. 3.) NM rendelet 2. melléklete szerint HIV-pozitív egészségügyi dolgozó a következő fertőzésveszélyes beavatkozásokat nem végezheti:

- testüregben történő sebészi beavatkozások, amelyek során a testüregben egyidejüleg van jelen a kéz vagy az ujjak, valamint tû és éles eszközök;

- mellkasi mútétek (például: szív- vagy tüdőmütét), hasi mütétek (gyomor-, vese-, májmútét stb.), ortopédiai mútétek;

- szüléslevezetés, császármetszés;

- illesztéssel járó véres traumatológiai mútétek, kiterjedt nagyfokú égési sérülések sebészi ellátása;

- orális, periorális szövetek, fogak kezelése, metszése, eltávolítása, amelyek kapcsán vérzés következhet be.

A jogszabály által előírt esetek kivételével az egyenlő bánásmódról és az esélyegyenlőség előmozdításáról szóló 2003. évi CXXV. törvény 8 . \$ h) pontja értelmében tiltott hátrányos megkülönböztetésnek minősül, ha az AIDS-es, illetve HIV-fertőzött munkavállalót egészségi állapota miatt kedvezőtlen bánásmódban részesítik vagy esetleg felmondják a munkaszerződését. A munkaszerződés ilyen okból való felmondása esetén a volt munkavállaló bírósághoz fordulhat, és kérheti, hogy a bíróság kötelezze volt munkáltatóját arra, hogy őt állásába viszszahelyezze. Hasonló helyzetekben a magyar bírósági gyakorlat arra enged következtetni, hogy az AIDS-es, illetve HIV-fertózött munkavállaló vissza fogja kapni az állását. Ha a munkáltató a betegségen kívül más, például a fizikai teherbírás csökkenésére utaló foglalkozás-egészségügyi adatot is szolgáltat az AIDS-es munkavállalóról, akkor a munkáltató eljárása jogszerünek bizonyulhat.

Ha bebizonyosodik, hogy a munkáltató jogellenesen járt el az AIDS-es, illetve HIV-fertőzött munkavállalóval szemben, akkor a volt munkavállaló a polgári törvénykönyv 2:43. $\$$ c) pontja értelmében hátrányos megkülönböztetésért objektív és szubjektív személyiségvédelmi szankciók alkalmazását kérheti. Objektív, tehát felróhatóságtól független személyiségvédelmi szankció például a jogsértés abbahagyására kötelezés és eltiltás a további jogsértéstől. Szubjektív, tehát felróhatóságtól függő szankcióként a sérelemdíj és a kártérítés jöhet szóba. A kártérítési felelősség és a sérelemdíj fizetésére kötelezés alól a munkáltató akkor mentesülhet, ha bizonyítja, hogy a személyiségi jog megsértését az ellenőrzési körén kívül eső olyan körülmény okozta, amellyel nem kellett számolnia, és nem volt elvárható, hogy a károkozó körülmény bekövetkezését elkerülje vagy a kárt elhárítsa. A munkáltató akkor is mentesül a felelősség alól, ha bizonyítja, hogy a munkavállaló személyiségi joga kizáró- 
lag a munkavállaló elháríthatatlan magatartása miatt sérült. [Vö. 2012: I. tv. 166. \$ (1)-(2) bekezdés.] Teljes munkabíró képességgel rendelkező AIDS-es betegnek történt munkáltatói felmondás esetén a munkáltató gyakorlatilag nem tudja kimenteni magát.

Az AIDS-es betegek, illetve a HIV-fertőzöttek alkothatnak de jure közösségeket. Létrehozhatnak például az érdekeik védelmére és társadalmi helyzetük elfogadtatására civil szervezeteket: többnyire egyesületet vagy alapítványt. Azonban a Ptk. 2:54. $\$(5)$ bekezdése értelmében az AIDS-es betegek közösségének tagja nem jogosult gyưlöletbeszéd (hate speech) esetén közösségi személyiségi jogait érvényesíteni. Tehát nem kérhet például kártérítést vagy sérelemdíjat, ha az AIDS-eseket nagy nyilvánosság előtt verbálisan súlyosan sértő vagy kifejezésmódjában indokolatlanul bántó megnyilvánulás éri. Az AIDS-esekkel szembeni kihívóan közösségellenes, bennük riadalmat keltő magatartás tanúsítása büntetőjogi értelemben megvalósítja a „közösség tagja elleni erőszak"-ot. Míg a polgári jogi védelem az AIDS-esek közösségét nem illeti meg, addig a közösségükkel szemben akár erőszak nélkül megvalósuló garázdaság büntetôjogi felelősséget alapoz meg.

Az egyenlő bánásmód követelményének megsértéséért az Egyenlő Bánásmód Hatóság 50 ezer forinttól 6 millió forintig terjedő bírságot szabhat ki. A bírság kiszabására csak akkor kerülhet sor, ha az eljárási határidőt betartják. Tehát a jogsértés bekövetkeztétől számított egy év elteltével bírságot nem lehet alkalmazni (objektív határidő). Azonban, ha a jogsértő magatartás vagy állapot folyamatos, akkor az egy évet ennek befejeződésétől kell számítani. Ez utóbbi rendelkezés a jogában sértett személy érdekét szolgálja, mert nem kell sietnie az első jogsértő magatartás után: ha a jogsértés folyamatos, akár hosszabb ideig is várhat, illetve ha később szerez tudomást a jog nyújtotta lehetőségről, akkor sem esik el ettől. A jogsértő állapot megszüntetésének elrendelése és egyéb szankciók kiharcolása érdekében a hatósági eljárás a jogsértés bekövetkezésétól számított három éven belül indítható (objektív határidő). Tehát csak a bírság, mint leginkább visszatartó erejü szankció, alkalmazása kötődik viszonylag rövid határidőhöz. A szubjektív határidők ennél is rövidebbek:

- bírság alkalmazására irányuló eljárást a hatóság a jogsértésről való tudomásszerzésétől számított három hónapon belül indíthat;

- az Egyenlő Bánásmód Hatóság eljárása a jogsértésről való tudomásszerzéstől számított egy éven belül kérhetô.

Mivel a tudomásszerzés időpontja ilyen természetű jogesetekben ritkán bizonyítható, jobbára az objektív határidők érvényesülnek. A 2003. évi CXXV. törvény $5 . \$ d$ ) pontja értelmében az egyenlő bánásmód követelményét - a törvényben felsoroltak mellett - minden munkáltató is köteles megtartani a foglalkoztatási jogviszony tekintetében. Ez az a törvényhely, amely az AIDSes munkavállalókkal szembeni egyenlő bánásmód köve- telményét - a Ptk. szerinti polgári jogi védelem mellett - közigazgatási jogi eszközökkel is biztosítja. A polgári jogi személyiségvédelmi szankció alkalmazásával párhuzamosan is lehet közigazgatási jogi szankciót alkalmazni. Az egyik jogérvényesítési út alkalmazása nem zárja ki a másikat. Amennyiben büncselekmény is megvalósul, a büntetőjogi szankcionálás szintén párhuzamosan lehetséges. Például, ha jelentős érdeksérelmet okozva vagy haszonszerzési célból az AIDS-es, illetve HIV-fertőzött személy személyes adatával visszaélnek, büntetőjogi felelösségre vonásnak is helye van.

Az Egyenlő Bánásmód Hatóság határozata ellen fellebbezés nem lehetséges, de a hatóság határozatának bírósági felülvizsgálatát lehet kérni a Fővárosi Közigazgatási és Munkaügyi Bíróságtól. Az Egyenlő Bánásmód Hatóság jogszabálysértése esetén a bíróság a hatóság határozatát hatályon kívül helyezi és a hatóságot új eljárás lefolytatására kötelezi. A bíróság tehát nem változtathatja meg az Egyenlő Bánásmód Hatóság határozatát. Arra csak a hatóságnak van hatásköre egy új eljárás keretében.

Polgári jogi szakágon és munkaügyi szakágon, valamint büntetőügyben is lehetőség van fellebbezésre. Ez azonban nem jelenti az eljárás időbeli elhúzásának lehetőségét. A jogsértést rövid időn belül szankciónak kell követnie ahhoz, hogy a jogbiztonság alkotmányos követelménye érvényesüljön.

\section{Az AIDS jogon túli hatása a büntetéskiszabás gyakorlatára Magyarországon}

A Fővárosi Ítélőtábla az 5.Bf.396/2011/15. számú, 2012-ben kelt ítéletében a pénzügyi búncselekményt (készpénz-helyettesítő fizetőeszközzel visszaélést) elkövető vádlott esetében enyhítő körülményként értékelte, hogy a vádlott AIDS-ben szenved, és e gyógyíthatatlan betegség miatt életkilátásai korlátozottak. A büncselekmény elkövetése nem állt sem közvetlen, sem közvetett összefüggésben az elkövető betegségével, mivel nem a kezelése költségeit kívánta fedezni a bűncselekményével. Ennek ellenére a bíróság enyhítő körülménynek tekintette az AIDS-et. A Fővárosi Ítélőtábla 2012-ben kelt, Bf.147/2012/9. számú ítéletében másodfokon enyhítette a rablásért elítélt elkövető büntetését, mivel az elkövető gyógyíthatatlan AIDS-betegségét enyhítő körülménynek tekintette. Az elkövető esetén az első fokon kiszabott fegyházbüntetést börtönbüntetésre szállította le, arra hivatkozva, hogy az elítélt a betegsége miatt nehezebben viseli a börtönkörülményeket, mint egy egészséges személy.

Az AIDS és a jog viszonya többrétű korreláció. Ahogy a magyar büntetőbírósági gyakorlatból látszik, az AIDSnek nemcsak egészségügyi jogi vonatkozásai lehetnek, hanem a szociális megítélésre gyakorolt hatás révén befolyásolhatja akár egy bünelkövető büntetésének nemét, 
illetve mértékét is. Ez utóbbi effektus olyan, jogon túli hatás, amely a bírósági joggyakorlatban válik valóra. Az AIDS-ben szenvedő elkövető a magyar bíróságok előtt jó eséllyel hivatkozhat a betegségére, amikor a szokásosnál enyhébb szankcióban reménykedik. Az AIDS ilyetén szociális hatása természetesen nem az AIDS-jog fó irányvonalához tartozik, de a jogban érzékelhető, jogon túli hatások is hozzá tartoznak az AIDS-jog hatásmechanizmusához.

\section{A HIV-szürés önkéntessége}

Az AIDS társadalmi megítélése a globális társadalmi értékrend szerint negatív: tehát az AIDS-es beteget a legtöbb társadalom kiközösíti. Az orvosi értékrend szerint szakmai-etikai kötelesség az AIDS-es beteg ellátása: nem szabad megtagadni az AIDS-es beteg kezelését, de ez nem jelenti, hogy a ma létező leghatékonyabb gyógyszereket is ingyen adná az állami egészségbiztosítás. Az AIDS-es betegek ellátásának de jure kötelessége szakmai szempontból inkább a beteg egyéb egészségi problémáinak kezelésére korlátozódik. A Magyar Orvosi Kamara Etikai Kódexének II. 5. pontja 7) alpontjának értelmében a súlyos vagy gyógyíthatatlan betegségek esetén kívánatos a fokozatos tájékoztatás alkalmazása, feltéve, hogy az a beteg érdekét szolgálja. A HIV-fertőzöttségről általában nem fokozatosan szerez tudomást az érintett személy, így az nem egy esetben öngyilkossághoz vezető mentális állapotot idéz elő. Az etikai kódex II. 14. pontjának (1) bekezdése értelmében etikai vétség a betegellátást korlátozó gazdasági döntéseket orvosszakmai érvekkel indokolni. Konkrét esetben az orvos nem keltheti annak látszatát, hogy a gazdasági korlátok ellenére a beteg optimális ellátásban részesül.

A 18/2002. (XII. 28.) ESzCsM rendelet 8. $\$$-a értelmében önként is lehet HIV-szürésre jelentkezni. Ez különösen ajánlott a rendelet 9 . $\$$-a értelmében fertőzésnek fokozottan kitett személyek esetén:

- a HIV-fertőzött személyek szexuális partnerei;

- a szexuális úton terjedő aktív nemi betegségben szenvedők és szexuális partnereik;

- a HIV-fertőzött anya vér szerinti gyermeke;

- kábítószert nem orvosi rendelvény alapján intravénásan alkalmazók;

- a HIV-vizsgálatot kötelezővé nem tevő büncselekmények elkövetői, akik büntetés-végrehajtási intézetben vagy rendőrségi fogdában előzetes letartóztatásban vannak, vagy már büntetésüket töltik;

- a harmadik országból érkező migránsok, ha őrzött szálláshelyen vannak.

\section{A HIV-szürés anonimitása}

Önkéntes szưrővizsgálat esetén az érintett személy kérheti, hogy személyazonosságát előzetesen se kelljen felfednie. Ha az érintett személy anonim HIV-szürésen vesz részt, akkor a vizsgálatra jelentkezőt az első vérvétel előtt az egészségügyi szolgáltató azonosító jellel és azonosító számmal látja el. Az azonosító jelet és az azonosító számot az egészségügyi szolgáltató a vizsgált személyrôl felvett egészségügyi dokumentációban rögzíti és igazolást ad róla a HIV-szűrésen részt vevőnek. Az első szűrővizsgálat céljából levett vért az azonosító jellel, számmal, a vérvétel időpontjával és helyével ellátva küldik a laboratóriumba. Ha az eredmény pozitív, egy újabb vérvétellel kell meggyőződni, hogy a személy valóban HIV-fertőzött-e. Ha a HIV-fertózöttség bebizonyosodik, a beteget tájékoztatni kell az egészségügyi gondozás lehetőségéről, valamint fel kell hívni a figyelmét arra, hogy szexuális partnereit is tájékoztassa a HIV-szűrés szükségességéról. A gondozás igénybevétele a HIV-fertőzött személy szabad egészségügyi önrendelkezési joga szerint alakul. Ha a beteg nem kíván élni ezzel a lehetőséggel, arra nem lehet őt kötelezni. A szexuális partnerek tájékoztatásáról a magánélethez való jog alapján a HIVfertőzött személy szabadon dönthet. Talán a magánélethez füződő szabadságjog ilyen tág értelmezését nem célszerü a jövőben fenntartani, mivel az már más személy élethez és testi egészséghez füződő emberi jogát sértheti. Alaptörvényünk XX. cikke szerint mindenkinek joga van a testi és lelki egészséghez. Ezt Magyarország - egyebek mellett - az egészségügyi ellátás megszervezésével segíti elő. Ha a HIV-fertőzött személy szexuális partnere a tájékoztatás elmaradása miatt elesik ettől a jogtól, akkor sérül a jogbiztonság követelménye.

Nem anonim HIV-szűrés esetén is kötelező biztosítani az egészségügyi adatok védelmét. Ebben az esetben a vizsgált személy nevét, lakcímét és taj-számát a vérvételt végző orvos rögzíti. A laboratóriumba küldött vérhez csatolt kísérőlap csak a vizsgált személy taj-számát és a vérvétel időpontját tartalmazhatja. A vizsgált személy nevét, lakcímét és taj-számát úgy kell kezelni, hogy azokhoz illetéktelenek ne férhessenek hozzá.

A megerősítetten HIV-pozitív személyek gondozását Magyarországon a következő egészségügyi szolgáltatók végzik:

- Budapesten az Egyesített Szent István és Szent László Kórház-Rendelőintézet,

- Budapesten a Semmelweis Egyetem Bőr-, Nemikórtani és Bőronkológiai Klinikája,

- Debrecenben a Kenézy Gyula Kórház és Rendelőintézet,

- a Miskolci Semmelweis Kórház és Egyetemi Oktatókórház,

- a Pécsi Tudományegyetem I. Belgyógyászati Klinikája. Az anonimitás lényege, hogy ne lehessen személy szerint beazonosítani, ki tartozik a HIV-fertőzött, AIDS-es személyek közösségéhez. Ez alól két irányban van eltérés ma Magyarországon. Az egyik, amikor az AIDS-beteg személyek önként felvállalják - akár közéleti szereplőként is - a betegségüket, és a médiatartalom-szolgáltatók elé állnak, hogy közösségük érdekeit képviseljék és véleményt nyilvánítsanak egyes társadalmi-politikai kérdésekben. A magyar polgári törvénykönyv 2:44. $\$$-a szerint 
a közügyek szabad vitatását biztosító alapjogok gyakorlása a közéleti szereplő személyiségi jogainak védelmét szükséges és arányos mértékben, az emberi méltóság sérelme nélkül korlátozhatja. Így a közéleti szereplőként fellépő AIDS-beteg személy betegsége többé nem marad titokban, és akár bántó véleménynyilvánításoknak is ki lehet téve. Azt, hogy az AIDS-es közszereplő a személyiségi jogainak milyen mértékű korlátozását köteles eltűrni, a bírósági joggyakorlat feladata meghatározni. E tekintetben a magyar bíróságok egységes gyakorlatot kell, hogy kialakítsanak.

Az AIDS-es személyek anonimitási lehetősége alóli másik eltérés abból adódik, ha a HIV-szưrést követően pozitív eredményt produkáló személy nem él az anonimitás lehetőségével:

- egyrészt, mert eleve nem kért névtelen szürést, és ezzel felvállalta, hogy az egészségügyi szolgáltatások rendszere előtt ismertté válik a betegsége;

- másrészt, mert az anonim szürést követően, a pozitív eredmény tudatában gondozást igényel, ami óhatatlanul is az anonimitás ellen hat, mivel ismeretlen személyt nem lehet gondozni; a gondozást igénylő beteg tehát valamelyest felfedi magát az egészségügyi közigazgatás rendszere előtt.

$\mathrm{Az}$ anonimitás lényege a személyiség védelme. Az egészségügyi önrendelkezési képességgel rendelkező személy szabadon dönthet erről. A törvényes képviselővel eljáró személy egészségügyi önrendelkezési joga korlátozott, de ez nem mehet az ember mint jogalany élethez és testi-lelki egészséghez füződő jogának rovására.

Az AIDS-beteg személyek anonimitásának problematikája nemcsak megoldásra váró jogi feladatokat generál, hanem az AIDS és az etika kérdéskörét is érinti. A Magyar Orvosi Kamara Etikai Kódexének II. 3. pontja értelmében az adatkezelésre, a titoktartásra és az egészségügyi dokumentáció vezetésére és kezelésére vonatkozó jogszabályi rendelkezések vétkes megszegése egyben etikai vétségnek is minősül.

\section{Latencia és tévhitek}

Az Országos Epidemiológiai Központ adatai szerint 1985-ben 16 regisztrált HIV-fertőzött volt Magyarországon. 1995-ben már 81-en, 2005-ben 107-en, míg 2015-ben 201-en voltak. 2005-ben a regisztrált 107 HIV-fertőzöttből 10-en voltak névtelenek, míg 2015ben 201-ből 37-en őrizték meg anonimitásukat. A nem anonim HIV-fertőzöttek ismert adatai szerint a HIVfertőzött férfiak száma többszöröse a HIV-fertőzött nőkének, és ez az évek folyamán végig így alakul. A HIVvel összefüggő halálozások száma elenyészően alacsony Magyarországon, de körükben is nagyobb a férfiak aránya, mint a nőké [1]. Ezen adatok iránymutatóak, de nem láttatják a pontos valóságot. A valódi számok kiderítését több egészségügyi jogi rendelkezés akadályozza. E rendelkezések főleg a HIV-fertőzöttek személyiségi jogait szolgálják, és a többség érdekei nem írhatják felül e jogokat.

A HIV-fertőzöttség latens jellegén járványügyi szempontból mindenképpen változtatni kellene a közeli jövőben. A latens HIV-fertőzöttek száma akár sokszorosa lehet az ismert HIV-fertőzöttekének. Mivel ez az érv ijesztő lehet a lakosság számára, fontos volna tisztázni, hogy valóban nagy számban élnek-e a magyar lakosságban HIV-fertőzöttek, vagy ez indokolatlan aggodalom. Ahhoz, hogy egészen tisztán lássunk, számos jelenlegi jogállami szabályt meg kellene szegni, így ez nem elérhető cél. A lakosság megnyugtatására és a HIV-fertőzés továbbterjedésének megakadályozására léteznek olyan megoldások is, amelyek nem sértik a jogállamiságot és adekvát választ adnak a magyar lakosság aggodalmaira. Ilyen megoldás lehet:

- a kötelező HIV-szürés személyi hatályának olyan irányba történő kiterjesztése, hogy a megerősített pozitív eredményt produkálók anonimitása a munkahelyük és az egészségügyi szolgáltató előtt megmaradjon; ehhez a HIV-teszt elvégeztetéséhez kötött munkakörök számát emelni kell úgy, hogy csak a HIVteszt elvégeztetése legyen kötelező, de a pozitív HIVteszt ne legyen kizáró ok a foglalkoztatásnál;

- a másik lehetőség az anonim HIV-szürések népszerüsítése a médiatartalmak és a felsőfokú oktatás útján; így az anonimitás megmarad, de a HIV-fertőzöttek számáról megbízható és valós képet kapunk;

- további lehetőség volna az egészségügyi szolgáltatónál benn fekvő páciensek kötelező HIV-szűrése; ez a zárt környezetben könnyen átadható fertőzés veszélyét csökkentené, és a betegfelvételt követő rutinvizsgálatként, az anonimitás megőrzése mellett, mind járványügyi, mind statisztikai érdekből célszerü lenne; az adatvédelemre ekkor is fokozottan ügyelni kell.

A jogi latencia problémája a konkrét társadalmi probléma jogi átláthatóságának, jog általi érzékelhetőségének hiányát jelenti. Míg 1989 előtt a jogi latencia fogalmát elsôsorban az egységes nyomozóhatósági és ügyészségi statisztikából kimaradó bünesetekre értették, addig mára - éppen a demokratikus jogállamiság fejlett jogvédelmi eszközei miatt - a jogi latencia tárgyköre és személyi köre bővült. A potenciális veszélyt hordozó, gyógyíthatatlan betegségben szenvedő személyek egy meghatározatlan nagyságú hányada kívül esik a jog látókörén, és ôk inkább csak akkor válnak a jog számára láthatóvá, ha bưncselekményt követnek el. Nem helyes, ha a megelőzhető bûnesetek a megelőzés elégtelensége miatt következnek be. Mindazonáltal a gyógyíthatatlan betegségben szenvedőket nem tekinthetjük potenciális bűnözőknek. Az állam és a társadalom szétválasztásából eredően jogi latencia a társadalmi-gazdasági múködés más területein is ismert. Nem jó, ha a demokratikus jogállam a jogi latencia teljes megszüntetésére törekszik, mert az a totális állam múltból ismert negatív jelenségéhez vezethet. A jogi latencia csökkentése felé tett lépések csak addig elfogadhatók, amíg nem borítják fel az állam és társadalom egyensúlyát. 


\section{A HIV-fertózés jogi prevenciója}

A magyar Btk. értelmében, aki más személyt HIV-vírussal megfertőz, a testi sértés súlyos egészségromlást okozó, minősített esetét valósítja meg. A szándékos elkövetés (egyenes vagy eshetőleges szándék) a hétköznapi HIV-fertőzött személy és a lakosság többsége számára egyértelmúen bû́n: erkölcsi és jogi értelemben egyaránt. A büntetési tétel egy évtől öt évig terjedő szabadságvesztés. A gondatlan (tudatos gondatlanság vagy hanyagság) elkövetés a legtöbb esetben nem váltja ki a társadalom negatív erkölcsi ítéletét, és a magyar büntető törvénykönyv is mindössze egy évig terjedő szabadságvesztéssel rendeli büntetni. Tekintettel arra, hogy a HIV-vel történő megfertőzés esetén kialakuló AIDS jelenleg lege artis medicinae nem gyógyítható, és így előbb vagy utóbb halálhoz vezet, az emberölés megállapíthatóságának kérdése is felmerül. A magyar büntetójog a HIV-vel történő megfertőzést nem tekinti az élet kioltására irányuló cselekménynek. Ezen a büntetőjogi szemlélet módosulása változtathat. Az emberölés súlyossága jobban igazodik a HIV-vel megfertőzött sértett helyzetéhez, de a HIV-fertőzöttek gondozásának lehetősége és a HIV-fertőzés és a halál bekövetkezte közötti időbeli távolság, valamint az, hogy nehéz kimutatni az elkövetési magatartás (a megfertőzés) és az eredmény (a halál) közti összefüggést, ma még nem indokolják a büntetőjogi felfogás szigorítását.

A magyarországi büntetési tételek a HIV-fertőzés jogi és társadalmi következményeinek súlyossága ellenére alacsonynak tekinthetôk. Az állam nincs felkészülve arra, hogy ezt a kérdést a büntetójogi prevenció eszközeivel is rendezni próbálja. A kártérítési felelősség és a sérelemdíj intézménye - mint a probléma polgári jogi rendezésének útja - határozottan hangsúlyosabb megoldást jelent. Ez az út hosszadalmas lehet, de az elszenvedett jogsérelem szempontjából a leghatékonyabb a jelenlegi magyar jogalkalmazói környezetben. Kellóen nagy összegú kártérítés, illetve sérelemdíj bírósági gyakorlata mellett a HIV-fertőzött személyek óvatosabban viszonyulnak a szexualitás és a védekezés kérdéséhez. A bizonyítási eszközök polgári eljárásban szabadon alkalmazhatók, de a bizonyítás nehézségén ez keveset változtat. Az orvosszakértői véleményekre és esetleges tanúvallomásokra támaszkodó igazságszolgáltatás többnyire nehezen eldönthetô kérdésben ítélkezik. A fertőző és a fertőzött személye között nem könnyű jogilag releváns összefüggést bizonyítani. Aki másnak jogellenesen kárt okoz, köteles azt megtéríteni, de nem állapítható meg az okozati összefüggés azzal a kárral kapcsolatban, amelyet a károkozó nem látott elôre és nem is kellett előre látnia.

Amennyiben a HIV-fertózött személy szexuális partnere tud a másik személy HIV-fertőzöttségéről, és ennek tudatában megy bele a szexuális kapcsolatba, akkor a károsult beleegyezése miatt a károkozás nem minősül jogellenesnek, tehát nem kell megtéríteni az okozott kárt. Bizonyítási nehézségbe ütközne, ha a tudottan HIV-fer- tőzött személlyel szexuális kapcsolatot létesítő, megfertőződő személy arra építené a jogi érvelését, hogy ő csak a szexuális kapcsolatba egyezett bele, nem pedig a megfertőződésbe. Ez utóbbi érveléshez a fertőzéssel való egészségveszélyeztetést és a fertőzéssel való egészségsértést HIV/AIDS esetén egymástól egyértelmúen elhatárolható cselekménynek kellene tekinteni, és a fertőzéssel való veszélyeztetésbe történt beleegyezést kártérítési jogi értelemben úgy értékelné a joggyakorlat, hogy az nem minősül egyúttal beleegyezésnek a veszély lehetőségéből egyenesen következő károkozásba. Ilyetén érvelésnek a gyakorlatban az igazságszolgáltatás nem adhat helyet, de az ügyvédi érvelésben elhangozhat.

Természetesen a fertózést nemcsak nemi úton lehet továbbadni, ezért a fentieket mutatis mutandis minden más, fertózéssel járó történeti tényállásra is alkalmazni kell. A HIV-fertőzés jogi prevenciója mellett az egészségügyi prevencióra is oda kell figyelni. Nem elég jogi normákkal akadályozni a jogsértések bekövetkeztét. Az egészségügy fejlesztése és az orvostudomány fejlődése nélkül, önmagukban a jogi eszközök nem jelentenek perspektívát a HIV-fertôzés elleni küzdelemben. Az orvostudományi kutatásokba csak szabad elhatározásból beleegyező HIV-fertőzött személyeket szabad bevonni. A Helsinki Deklaráció utóbbi szabálya nem akadálya annak, hogy a kutatók a HIV elleni gyógyszer kifejlesztéséhez az egészségügyi önrendelkezési szabadságot nem sértő eljárásokat alkalmazzanak. Az emberen végzett kutatáshoz hozzájáruló HIV-fertőzöttek anyagi juttatásban részesítése a kutatás első fázisában megengedett és elfogadott megoldás. Pusztán a gyógyulás reményében is akadhatnak a kutatásba beleegyező HIV-fertőzöttek, de az anyagi jutalmazás kezdeti lehetősége a gyógyszercégek pénzbeli érdekein túl, közvetve az állam egészségügyi és a lakosság egészségi érdekeit is szolgálja.

\section{Az orvos eszközkötelme}

Az orvos felelőssége az AIDS gyógyításakor sosem keletkeztet eredménykötelmet, mivel az AIDS-ből való teljes kigyógyulás lehetősége ma még nem valószerú. Így inkább eszközkötelemról beszélhetünk, mert az orvos köteles az orvostól elvárhatóan mindent megtenni az AIDS-ben szenvedő beteg gyógyulásáért, de nem tartozik polgári jogi (például kártérítési) felelősséggel, ha az AIDS-es beteg nem gyógyul meg vagy esetleg elhalálozik. Az orvos - és általában az egészségügyi szolgáltató e kötelem eszközkötelmi jellegére hivatkozva könnyen háríthatja a kártérítési követelést akár bíróság előtt, akár bíróságon kívüli, közvetítői eljárás során. Az orvos tehát nem az eredmény létrehozásáért (a beteg teljes meggyógyulásáért) felel, hanem csak a beteg gyógyításáert.

Az orvos felelőssége ritkán keletkeztet eredménykötelmet. AIDS kapcsán ez lehetetlen volna, de adódhatnak más orvosi kötelezettségvállalások, ahol eredménykötelem áll fenn: például, ha a fogorvos múfogsor készí- 
tését vállalja vagy a plasztikai sebész orr-, fül- vagy egyéb szépészeti beavatkozást vállal stb.

Az AIDS és más betegségek esetén az eredmény, tehát a teljes gyógyulás elérése nem várható el az orvostól. Ez akkor is így van, ha könnyen gyógyítható betegségről (például egyszerü, bakteriális bélfertőzésről) van szó és akkor is, ha gyógyíthatatlan betegségről (például AIDSrôl) beszélünk. A könnyen gyógyítható betegségnek is lehetnek súlyos szövődményei, amelyekért az orvos - ha úgy járt el, ahogy az egy orvostól elvárható - nem felel. Továbbá a korábbról az orvos számára nem ismert betegnek olyan egészségromlása vagy fogyatékossága is lehet, amelyről a kezelőorvos nem tud, így például egy immunhiányos betegre súlyosabb hatással lehet egy hétköznapi fertőzés, amelyből más, jó immunrendszerü beteg könnyen kigyógyulna.

\section{Az orvosi jog szerepe a HIV/AIDS leküzdésében}

Tamási Béla és szerzôtársai 2015-ben az Orvosi Hetilapban megjelent cikkükben rámutattak, hogy ma Magyarországon a HIV-fertőzött személyek mintegy fele nem tud a fertőzöttségéről. A szerzők maguk is tapasztalták a Semmelweis Egyetem Bőr-, Nemikórtani és Bőronkológiai Klinikáján azt az egyébként általános jelenséget, hogy a 18-25 éves korosztályban egyre többen fertőződnek meg HIV-vel [2].

$\mathrm{Az}$ orvosi jog nemcsak az orvos jogi felelősségével foglalkozik. Bár kétségtelenül ez a legfontosabb, empirikus kutatással is vizsgált orvosi jogi kérdés. Az orvosi jog része korunk pusztító betegségeinek társadalmi-jogi hatásait vizsgálni, és gyakorlatban is alkalmazható jogi megoldásokat keresni olyan betegségek szocioökonómiai következményeire, mint amilyen az AIDS is.

A betegségek elleni küzdelem a közegészségügy, a járványügy és az egészségfejlesztés feladata. Nem szúkíthetjük le az AIDS kérdését pusztán járványügyi problémává. Az egészségnevelés, az egészségmegőrzés, a kábítószer-fogyasztással foglalkozó gyermek- és ifjúságegészségügy, továbbá a család- és nővédelmi gondozás és a munkaegészségügy is érintett a HIV-fertőződés prevenciójában és az AIDS-es betegek jogi-társadalmi esélyegyenlőségének elősegítésében.

Nem korlátozhatjuk a HIV-fertőzött és az AIDS-ben szenvedő betegek emberi jogait. Ugyanakkor nem veszélyeztethetjük a lakosság egészséges tagjait. A jogi rendelkezések célja a HIV-fertőzöttek és az AIDS-es betegek jogainak maximális tiszteletben tartása mellett a társadalom védelme a gyógyíthatatlan betegség jelentette kockázatoktól:
- elsősorban a fertőződés rizikójának minimalizálásával; - másodsorban egyenlő esélyek és egyenlő bánásmód nyújtásával a HIV-fertőzött személyek számára.

A jogalkotási produktum (például törvény, rendelet) önmagában nem elegendő a HIV-fertőzés és az AIDS leküzdéséhez. A jogalkotó szándéka a jogot alkalmazó közigazgatás és igazságszolgáltatás, valamint a professzionális joghasználók (például ügyvédek) és a laikus joghasználók (például ügyfél, páciens) gyakorlati magatartása útján valósulhat meg. Ha ez a gyakorlati magatartás eltér a jogszabálynak a jogalkotó szándéka szerinti értelmezése alapján követendő magatartástól, akkor sokszor nem elég jogorvoslatot keresni egy magasabb fórum előtt: a jogalkotási termék újragondolására és újrafogalmazására is szükség van. Ha a gyakorlat eltér az írott jogban megjelenített jogalkotói szándéktól, a jogállamiság keretein belül jogszabály-változtatással kell helyreállítani a jogbiztonságot. Az írott jog nyújtotta jogbiztonság a demokratikus jogállamiság egyik alapértéke. Ez persze nem jelenti azt, hogy a természetjognak ne lenne hasznos funkciója a jogállamiság biztosításában.

Kereszty Éva írta „Halottak, akik köztünk élnek” című könyvében [3]: „... a halál elfogadtatása az élőkkel és a gyászoló túlélőkkel manapság nem egyszerű dolog. A tudomány, a technika és fóleg az orvostudomány annak ellenére sem mindenható, hogy sokan 'ezt várják el'.”

Anyagi támogatás: A közlemény megírása anyagi támogatásban nem részesült.

A cikk végleges változatát a szerző elolvasta és jóváhagyta.

Érdekeltségek: A szerzőnek nincsenek érdekeltségei.

\section{Irodalom}

[1] http://www.aidsinfo.hu/statisztika_magyar_t (Letöltve 2016. szeptember 6-án.) [Hungarian]

[2] Tamási, B., Marschalkó, M., Kárpáti, S.: Skin symptoms associated with human immunodeficiency virus infection. [A humán immundeficientia vírus fertőzéséhez társuló bőrtünetek.] Orv. Hetil., 2015, 156(1), 10-18. [Hungarian]

[3] Kereszty, É.: Dead people who live with us. [Halottak, akik köztünk élnek.] Medicina Könyvkiadó, Budapest, 2006. [Hungarian] 